\title{
Application of Maltodextrin-based Adhesive on Particleboard Made from Salacca Frond
}

\author{
Greitta Kusuma Dewi, Ragil Widyorini,* and Ganis Lukmandaru \\ Maltodextrin is a potential natural adhesive for particleboard because it is \\ reactive and freely soluble in water. However, maltodextrin has a low water \\ resistance and a high melting point that hinder its development as a \\ particleboard adhesive. An addition of ammonium dihydrogen phosphate \\ (ADP) as a catalyst of maltodextrin was expected to overcome its \\ weaknesses. The optimal pressing temperature was expected to be \\ affected due to the addition of catalysts. This research aimed to investigate \\ the effect of maltodextrin/ADP ratios and pressing temperatures on \\ particleboard properties made from Salacca frond. The maltodextrin/ADP \\ ratios used in this research were 100/0,90/10, and 80/20 wt\%, and the \\ pressing temperatures were set at 200 and $220^{\circ} \mathrm{C}$. The combination of an \\ increased ADP ratio in maltodextrin and an increased pressing \\ temperature improved the particleboard properties. The water resistance \\ was also significantly improved by addition of ADP and increased pressing \\ temperature. Thermal analyses showed that the onset temperature of \\ weight reduction of maltodextrin added particles was lowered by addition \\ of ADP. The results suggested that a maltodextrin/ADP mixture could be \\ a promising particleboard binder.
}

DOI: 10.15376/biores.17.1.190-206

Keywords: Maltodextrin; Ammonium dihydrogen phosphate; Particleboard properties; Pressing temperature; Salacca frond

Contact information: Department of Forest Product Technology, Faculty of Forestry, Universitas Gadjah Mada, Jl. Agro no. 1, Yogyakarta, Indonesia 55281; *Corresponding author: rwidyorini@ugm.ac.id

\section{INTRODUCTION}

The discovery of a new wood adhesive needs to be considered to address the formaldehyde-based adhesive problems. In 2016, formaldehyde was classified as a more toxic compound, from "suspected of causing" to "may cause" carcinogenicity and "suspected of causing" mutagenicity (Axelson 2015). Aside from health issues, formaldehyde is considered less environmental-friendly because its synthesis uses nonrenewable and limited-resource compounds, such as petroleum and natural gas. The usage shift of wood adhesives to non-formaldehyde adhesives has now become a concern. However, formaldehyde-based adhesives have supplied more than $60 \%$ of the global wood adhesive needs. The need for wood adhesives was predicted to increase year over year as the global production and consumption of wood panels also increases (FAO 2018). Substitutes for formaldehyde-based adhesives must be mass produced or consist of many different types of adhesives.

The exploration of natural adhesives becomes one solution because there are many varieties and the production can be increased through cultivation and biotechnology. Such adhesives also have the potential to be harmless for living things and the environment. 
Many natural adhesives have been used and investigated in composite board manufacturing such as soy flour, casein, blood albumin, chitosan, gluten, tannin, lignin, gum, shellac, rubber, citric acid, starch, etc. (Umemura et al. 2003; Moubarik et al. 2009; Lei et al. 2010; Umemura et al. 2011; Bertaud et al. 2012; Kollman et al. 2012; Norstrom et al. 2014; Widyorini et al. 2016). Recently, Umemura et al. (2017) found that sucrose/ADP (ammonium dihydrogen phosphate) is a promising wood adhesive because of its bonding ability and high-water resistance, as also reported by Zhao et al. (2018) and Widyorini (2020). Sucrose is abundant and available everywhere, but it is widely used as the main sugar in food and drinks, and its usage for commercial wood adhesives may experience obstacles. Another saccharide with potential that only is being used as an additive in the food and drink industry is maltodextrin.

Maltodextrin consists of $\beta$-d-glucose oligomers that have a dextrose equivalence (the amount of reducing sugar presented based on total dry substance) of less than 20 (Bemiller and Whistler 1996). It is produced by acid or enzyme hydrolysis of starch, which is abundant. Maltodextrin has better adhesion properties than starch, is easy to obtain, and is freely soluble in water (Clare et al. 2002; Rowe et al. 2009; Castro-Cabado et al. 2016). Compared to sucrose, maltodextrin is cheaper in price. However, development of maltodextrin as a wood adhesive faces challenges, i.e. a high melting point and its particleboard has low dimensional stability. The maltodextrin melting point is higher than $225^{\circ} \mathrm{C}$ (Mollan and Çelik 1996), which means that the bonding and curing reactions occur at higher temperatures, as well as the optimal pressing temperature in particleboard manufacturing. Santoso et al. (2017) states that the thickness swelling (TS) of nipa frond particleboard with $20 \mathrm{wt} \%$ maltodextrin does not meet the Japanese industrial standard (JIS) A 5908 (2003) for particleboard at both 180 and $200{ }^{\circ} \mathrm{C}$ pressing temperatures but meets the standard only after a minimum $12.5 \mathrm{wt} \%$ addition of cross linker citric acid. In addition, Zhao et al. (2018) and Widyorini (2020) have successfully improved properties of recycled wood particleboard and bamboo particleboard, respectively, by addition of ADP.

The addition of ADP is predicted to overcome maltodextrin weaknesses and better optimize its usage as a particleboard wood adhesive. According to Umemura et al. (2017), the ADP catalyst lowers the sucrose melting point. Maltodextrin and sucrose have some features in common, i.e. they were both dehydrated and rearranged/caramelized in thermal treatment (Claude and Ubbink 2006; Quintas et al. 2007). Caramelization basically is a rearrangement process that leads to 5-hydroxymethyl 2-furfural (5-HMF) formation, and there are 4 concepts that lead to the process, i.e. 1) thermal treatment of pure saccharides above their melting points, 2) thermal treatment of saccharides in the presence of catalyst, 3) treatment of saccharides in mineral acids or alkali, and 4) treatment with ammonia, ammonium salts, amino acids, protein and polypeptides that cause the Maillard reaction (Tomasik et al. 1989). Because maltodextrin acts differently than disaccharides sucrose, the effects of adding ADP and the optimal pressing temperature to product high-quality particleboard could be different. The authors' previous study showed a decrease of the maltodextrin melting point from 272 to $204{ }^{\circ} \mathrm{C}$ and an increase of water resistance of the heat-treated maltodextrin after ADP addition (Dewi et al. 2020). However, the adhesiveness of maltodextrin and ADP for lignocellulosic materials has not been investigated.

Salacca frond was chosen as the raw material because it works well in citric acid/maltodextrin particleboard $(75 / 25 \mathrm{wt} \%)$. The three-layer particleboard with its finer particles or its fibrovascular bundles (length was $25 \pm 5 \mathrm{~mm}$ ) as the face layer was also 
successfully produced. The board properties met JIS A 5908 standard (Prasetyo et al. 2017; Widyorini et al. 2018; Widyorini et al. 2020). Those fronds usually are left over to rot in the plantation area during intensive plant maintenance, and the resource has not been used extensively yet (BPPT 2000; Lim 2012; Widyorini et al. 2018; Hakim et al. 2019). The Salacca plant has been widely cultivated in south-east Asia plantation in Indonesia, Malaysia and Thailand, and particularly in Indonesia's agroforestry area for its fruit production (Saleh et al. 2018; Hakim et al. 2019). Statistic Indonesia (2019) noted that a total number of harvested Salacca plant in the fourth quarter of 2018 in Indonesia was $38,024,008$ clumps at 27,731 ha plantation area. They usually prune 2 to 3 fronds per clump every 2 months to stimulate the female flower formation for fruit production, so the estimated biomass of the frond is more than 144 million tons/year in Indonesia (the weight of 2 to 3 fronds is about 0.5 to $1 \mathrm{~kg}$ ). Based on that, it was concluded that the fronds are potential materials to be developed for particleboard industry. This research aimed to utilize Salacca frond and investigate the effect of ADP ratios in maltodextrin and pressing temperatures on the properties of particleboard made from it, as well as to find the best manufacturing conditions.

\section{EXPERIMENTAL}

\section{Materials}

Food grade maltodextrin DE 10-15 was purchased from Zhucheng Dongxiao Biotechnology Co. Ltd, (Zhucheng, China) without further purification. Ammonium dihydrogen phosphate pro analysis (PA) CAS No. 7722-76-1 (Merck, Darmstadt, Germany) was also used as catalyst without further purification and distilled water was used as the solvent.

Salacca (Salacca zalacca) fronds were collected from Turi district, Sleman city, Yogyakarta province, Indonesia. Before being processed into particles, Salacca fronds were cleaned of thorns, and the tips were cut and discarded (Salacca frond length used for particle production was $\pm 2 \mathrm{~m}$ from the frond base). They were then cut with a chipper and air-dried. The particle production used a knife ring flaker. The particles were screened through a 10-mesh screen, and the particles that passed through the mesh were used as the raw material. Roughly $84 \%$ were passed through the 10 -mesh and 40 -mesh was retained. The raw material had a $12.3 \%$ moisture content and $0.130 \pm 0.002 \mathrm{~g} / \mathrm{cm}^{3}$ bulk density.

\section{Method}

\section{Adhesive solution preparation}

The maltodextrin was dissolved in warm distilled water $\left(80 \pm 2{ }^{\circ} \mathrm{C}\right)$ at a $50 \mathrm{wt} \%$ concentration because maltodextrin DE 10-15 demonstrates good solubility in the solids range of 45 to $65 \%$ (Kenyon and Anderson 1988). After being completely dissolved, certain amounts of ADP catalyst were added. The maltodextrin/ADP mixture ratios were $100 / 0,90 / 10$, and $80 / 20 \mathrm{wt} \%$. The adhesives content used in this research was $20 \mathrm{wt} \%$ based on dry weight particles. The viscosity and $\mathrm{pH}$ of each adhesive solution is shown in Table 1. 
Table 1. Viscosity and $\mathrm{pH}$ of Adhesive Solutions at $43 \pm 2{ }^{\circ} \mathrm{C}$

\begin{tabular}{|c|c|c|c|}
\hline \multirow{2}{*}{ Properties } & \multicolumn{3}{|c|}{ Maltodextrin/ADP Ratio (wt\%) } \\
\cline { 2 - 4 } & $100 / 0$ & $90 / 10$ & $80 / 20$ \\
\hline Viscosity (cP) & 131.2 & 125.8 & 106.4 \\
\hline $\mathrm{pH}$ & 6.22 & 3.91 & 3.61 \\
\hline
\end{tabular}

\section{Particleboard manufacturing}

The adhesive solutions at warm conditions $\left(43 \pm 2{ }^{\circ} \mathrm{C}\right)$ were evenly sprayed onto particles, as reported by Widyorini et al. (2017). Solution additions were completed in warm conditions because they had considerably lower viscosity compared to their viscosity at room temperature. The sprayed particles were oven dried at $80{ }^{\circ} \mathrm{C}$ for $4 \mathrm{~h}$ to reduce moisture content and avoid board delamination (the moisture content of the sprayed particles was reduced from 26.2 to $33 \%$ to 4 to $5 \%$ after oven drying). The particles were hand formed into mats in $25 \mathrm{~cm}$ x $25 \mathrm{~cm}$ sizes and then were hot-pressed using a three-step cycle, as reported by Widyorini et al. (2018) at $3 \mathrm{MPa}$ specific pressure. The mats were hot-pressed for $5 \mathrm{~min}$, had a $1 \mathrm{~min}$ breathing stage, and then hot-pressed again for $5 \mathrm{~min}$. The total pressing time was $10 \mathrm{~min}$. The board dimension was targeted in $25 \mathrm{~cm} \times 25 \mathrm{~cm}$ $\mathrm{x} 1 \mathrm{~cm}$ in size with a target density of $0.8 \mathrm{~g} / \mathrm{cm}^{3}$. All boards were conditioned for approximately 1 week at room temperature $\left( \pm 27^{\circ} \mathrm{C}\right)$ and a $77 \%$ relative humidity before board property evaluations.

\section{Board properties evaluation}

The boards were evaluated according to their physical properties, such as density, moisture content, thickness swelling, and water absorption, as well as by their mechanical properties, such as internal bonding strength, bending strength (modulus of rupture and modulus of elasticity), and bending strength under wet conditions. The surface roughness was also evaluated for finishing purposes information. The properties were evaluated according to JIS A 5908 (2003), except that the water absorption was evaluated based on Clarke (1966) and the surface roughness was evaluated based on Hiziroglu and Suzuki (2007).

The density (D), moisture content (MC), thickness swelling (TS), water absorption (WA), and internal bonding strength (IBS) tests were performed on a $5 \mathrm{~cm} \times 5 \mathrm{~cm} \times 1 \mathrm{~cm}$ specimen, while the bending strength, bending strength under wet conditions, and surface roughness tests were performed on a $20 \mathrm{~cm} \times 5 \mathrm{~cm} \times 1 \mathrm{~cm}$ specimen. The density was determined by dividing the weight sample with its volume. The moisture content was determined as the percentage of weight changes after oven drying based on the constant air-dried weight. The thickness swelling and water absorption were tested by immersing the specimen in water at room temperature for $24 \mathrm{~h}$. The internal bonding strength was tested by pulling the specimen surface perpendicularly at a load speed $2 \mathrm{~mm} / \mathrm{min}$ before failing force. The bending strength i.e. modulus of rupture (MOR) and modulus of elasticity (MOE) were tested by giving load vertically on the board face at rate $10 \mathrm{~mm} / \mathrm{min}$ and span $15 \mathrm{~cm}$ until maximum load before cracking. The same test was performed through a wet bending strength evaluation where the specimen was immersed in warm water at 70 $\pm 3{ }^{\circ} \mathrm{C}$ for $2 \mathrm{~h}$ and continued immersed in water at room temperature for $1 \mathrm{~h}$ (wet bending test A) prior to the test. Before the wet bending test, surface roughness was measured as the average roughness $\left(R_{\mathrm{a}}\right)$ using a surface roughness tester (SRG 4000, Bosworth Instrument, Cleveland, OH, USA) at six random points. The bending strength reduction (\%) was calculated by subtracting the wet bending strength from the dry bending strength, 
and divided by the dry bending strength. The MOR, MOE, and IBS values were corrected in target density based on specimen densities. Each property was tested in triplicate (except the wet bending strength was tested in duplicate) and the average and standard deviation were determined. A two-ways analysis of variance (ANOVA) with $\alpha 1 \%$ and 5\% was conducted to show the effect of maltodextrin/ADP ratios and pressing temperatures on the board properties.

\section{Fourier Transform Infrared (FTIR) spectroscopy}

A FTIR analysis was performed by a FTIR spectrophotometer (IR Prestige-21, Shimadzu, Kyoto, Japan) using a $\mathrm{KBr}$ disk method and were recorded by means of a 10 scan average at a $16 \mathrm{~cm}^{-1}$ resolution. The wet bending specimen were used as the samples to remove the excess and unreactive maltodextrin in particle bonding for the results. In addition, the materials of heat-treated adhesive after boiling for $4 \mathrm{~h}$ (Dewi et al. 2020) as well as Salacca frond (Widyorini et al. 2018) were also analyzed. Each sample was ovendried at $40{ }^{\circ} \mathrm{C}$ overnight and ground into powder (smaller than passed through $100 \mathrm{mesh}$ ). Prior to the analysis, the sample was oven-dried again at $60{ }^{\circ} \mathrm{C}$ for $15 \mathrm{~h}$.

\section{Thermogravimetry Analysis (TGA)}

A thermogravimetry analysis was performed through a simultaneous thermal analyzer (PT 1600, Linseis, Selb, Germany). Maltodextrin with/without ADP catalyst was dissolved in warm distilled water at the maltodextrin/ADP ratios of 100/0 and 80/20 wt\% with the concentration of the solution was $50 \mathrm{wt} \%$. Each solution was then sprayed into particles and dried at $80{ }^{\circ} \mathrm{C}$ for $4 \mathrm{~h}$. After drying, the samples were pulverized into less than 60 mesh size and served as the TGA samples. In addition, dried mixture of maltodextrin/ADP ratios of 80/20 wt\% (Dewi et al. 2019) were also added to be analyzed. The samples were scanned from room temperature $\left( \pm 27^{\circ} \mathrm{C}\right)$ to $400{ }^{\circ} \mathrm{C}$ at a rate $10^{\circ} \mathrm{C} / \mathrm{min}$ under nitrogen purging. The flow rate of nitrogen purging is $40 \mathrm{~mL} / \mathrm{min}$.

\section{RESULTS AND DISCUSSION}

All boards were manufactured without delamination, and the particleboard color became darker as the ADP ratio in the maltodextrin and pressing temperature increased. This phenomenon was also found in citric acid particleboard and binderless particleboard with ADP additions (Widyorini et al. 2016; 2018; Komariah et al. 2019). Darker colorization of the boards may due to the simple sugar caramelization produced by ADPhydrolyzed maltodextrin and also a high degree of raw material hydrolysis during high pressing temperatures.

The analysis of variance (ANOVA) of the board properties are shown in Table 2. Interactions between the maltodextrin/ADP ratio and pressing temperature affected board properties related to water, such as thickness swelling, water absorption, modulus of rupture under wet conditions, and modulus of elasticity under wet conditions. Interestingly, those interactions did not affect the modulus of rupture or modulus of elasticity under dry conditions. The maltodextrin/ADP ratios affected internal bonding and modulus elasticity under dry conditions notably but did not affect modulus of rupture under dry conditions. 
Table 2. Analysis of Variance

\begin{tabular}{|c|c|c|c|}
\hline \multirow[b]{2}{*}{ Properties } & \multicolumn{3}{|c|}{ Significance (p-value) } \\
\hline & $\begin{array}{c}\text { Maltodextrin/ADP } \\
\text { Ratios }\end{array}$ & $\begin{array}{c}\text { Pressing } \\
\text { Temperature }\left({ }^{\circ} \mathrm{C}\right)\end{array}$ & $\begin{array}{l}\text { Maltodextrin/ADP } \\
\text { Ratios* Pressing } \\
\text { Temperature }\end{array}$ \\
\hline Thickness Swelling & $1.133 \times 10^{-8 * *}$ & $1.188 \times 10^{-8 * *}$ & $5.277 \times 10^{-3 * *}$ \\
\hline Water Absorption & $3.926 \times 10^{-8 * *}$ & $3.921 \times 10^{-7 * *}$ & $0.034^{*}$ \\
\hline Surface Roughness & $0.006^{* *}$ & $4.704 \times 10^{-7 * *}$ & $0.866 \mathrm{~ns}$ \\
\hline Internal Bonding Strength & $1.776 \times 10^{-4 * *}$ & $2.850 \times 10^{-6 * *}$ & $0.159 \mathrm{~ns}$ \\
\hline $\begin{array}{l}\text { Modulus of Rupture under } \\
\text { Dry Conditions }\end{array}$ & $0.055 \mathrm{~ns}$ & $0.159 \mathrm{~ns}$ & $0.346 \mathrm{~ns}$ \\
\hline $\begin{array}{l}\text { Modulus of Elasticity } \\
\text { under Dry Conditions }\end{array}$ & $0.009^{* *}$ & $0.342 \mathrm{~ns}$ & 0.264 ns \\
\hline $\begin{array}{c}\text { Modulus of Rupture Under } \\
\text { Wet Conditions }\end{array}$ & $2.829 \times 10^{-5} * *$ & $1.251 \times 10^{-4}$ ** & $0.012^{*}$ \\
\hline $\begin{array}{l}\text { Modulus of Elasticity } \\
\text { under Wet Conditions }\end{array}$ & $2.525 \times 10^{-5 * *}$ & $1.556 \times 10^{-5 * *}$ & $0.003^{* *}$ \\
\hline
\end{tabular}

Note: ns: non-significant, ${ }^{*}$ : significant at $5 \%$ test level, ${ }^{*}$ : significant at $1 \%$ test level

\section{Physical Properties and Surface Roughness of Boards}

Table 3 shows the physical properties and surface roughness of the boards. All boards had densities ranging from 0.74 to $0.78 \mathrm{~g} / \mathrm{cm}^{3}$, although the target density was 0.8 $\mathrm{g} / \mathrm{cm}^{3}$. The lower density compared to the target density was likely due to board widening ( 2 to $5 \%$ ) after hot-pressing process. All moisture contents (MC) of the boards met the requirement of JIS A 5908 (5 to 13\%) as the MC range was 5.75 to $7.59 \%$. An increase of the maltodextrin/ADP ratio and the pressing temperature resulted in a decreased moisture content of the board. Two causes could have led to these results, i.e. the bonding formation between maltodextrin and particles that was accelerated by ADP additions could have reduced the free $\mathrm{OH}$-groups in particles to bond with moisture in its surroundings, and severe dehydration of the raw material during hot pressing caused a hysteresis effect. Higher temperatures caused greater chemical structure changes in the wood, such as lignocellulose decomposition and cellulose crystallinity increases, which led to the equilibrium moisture content to become lower, known as wood hysteresis (Akyildiz and Ates 2008; Esteves and Pereira 2009).

The TS and WA values ranged from 6.25 to $73.16 \%$ and 35.5 to $151.8 \%$, respectively (Table 3). Only the boards with an $80 / 20 \mathrm{wt} \%$ maltodextrin/ADP ratio and a $220{ }^{\circ} \mathrm{C}$ pressing temperature met the TS standard of JIS A 5908 requirement (max. 12\%), while the $80 / 20 \mathrm{wt} \%$ maltodextrin/ADP boards at both pressing temperatures and the $90 / 10$ wt $\%$ maltodextrin/ADP boards at $220{ }^{\circ} \mathrm{C}$ had WA values that met the WA values range of particleboard stated by Clark (1966) (20 to 75\%). The 100/0 wt $\%$ maltodextrin/ADP boards at both pressing temperatures had low dimensional stability and water resistance. The bonding system of maltodextrin $100 \%$ and particles might not have been formed entirely, as the melting point of maltodextrin is higher than $225{ }^{\circ} \mathrm{C}$ (higher than the pressing temperature used); in addition, maltodextrin has properties, i.e. freely soluble in water and high wettability (Mollan and Çelik 1996; Wang and Wang 2000; Rowe et al. 2009) that make the bonding system easy to break in the presence of excess water. Hydrogen bonds formed by maltodextrin and lignocellulose is also easily broken by water. Breakages in the adhesives bond network and potential thickness recovery of densified particles are factors affecting TS values of resin-bonded particleboard (Sekino et al. 1999). 
Table 3. Density (D), Moisture Content (MC), Thickness Swelling (TS), Water Absorption (WA), and Surface Roughness (SR) of Maltodextrin/ADP-based Particleboard

\begin{tabular}{|c|c|c|c|c|c|c|}
\hline \multirow{2}{*}{ Properties } & \multicolumn{6}{|c|}{ Maltodextrin/ADP Ratio (wt\%) } \\
\cline { 2 - 7 } & \multicolumn{2}{|c|}{$100 / 0$} & \multicolumn{2}{c|}{$90 / 10$} & \multicolumn{2}{c|}{$80 / 20$} \\
\cline { 2 - 7 } & $200{ }^{\circ} \mathrm{C}$ & $220^{\circ} \mathrm{C}$ & $200{ }^{\circ} \mathrm{C}$ & $22{ }^{\circ} \mathrm{C}$ & $200{ }^{\circ} \mathrm{C}$ & $22{ }^{\circ} \mathrm{C}$ \\
\hline $\mathrm{D}\left(\mathrm{g} / \mathrm{cm}^{3}\right)$ & $0.74 \pm 0.00$ & $0.78 \pm 0.02$ & $0.75 \pm 0.02$ & $0.78 \pm 0.01$ & $0.77 \pm 0.01$ & $0.78 \pm 0.02$ \\
\hline $\mathrm{MC}(\%)$ & $7.59 \pm 0.1$ & $7.01 \pm 0.1$ & $7.13 \pm 0.1$ & $6.16 \pm 0.4$ & $5.99 \pm 0.9$ & $5.75 \pm 0.3$ \\
\hline $\mathrm{TS}(\%)$ & $73.16 \pm 8.6$ & $35.61 \pm 3.8$ & $48.30 \pm 3.2$ & $17.73 \pm 1.5$ & $23.23 \pm 4.1$ & $6.25 \pm 0.8$ \\
\hline $\mathrm{WA}(\%)$ & $151.8 \pm 14.1$ & $93.1 \pm 6.4$ & $97.5 \pm 4.1$ & $66.3 \pm 12.0$ & $68.8 \pm 7.6$ & $35.5 \pm 2.7$ \\
\hline $\mathrm{SR}(\mu \mathrm{m})$ & $8.14 \pm 0.5$ & $6.16 \pm 0.1$ & $7.77 \pm 0.8$ & $5.63 \pm 0.3$ & $7.21 \pm 0.6$ & $4.94 \pm 0.2$ \\
\hline
\end{tabular}

Results showed a downward trend of TS and WA values with increased maltodextrin/ADP ratios and pressing temperatures. At $220{ }^{\circ} \mathrm{C}$ pressing temperature, the TS value was $35.61 \%$ and decreased to $17.73 \%$ and $6.25 \%$ after addition of $10 \%$ and $20 \%$ ADP in maltodextrin, respectively. The WA decreased from $93.1 \%$ to $66.3 \%$ and $35.5 \%$, respectively. There was a greater decrease in values at a $220{ }^{\circ} \mathrm{C}$ pressing temperature than $200{ }^{\circ} \mathrm{C}$. Umemura et al. (2017) states that ADP can lower the melting point of sucrose and change sucrose to a high water-resistant substance containing a furan ring and carbonyl group by heat treatment. High pressing temperature and the presences of ADP in the maltodextrin bonding system might also turn maltodextrin into a high water-resistant substance, although maltodextrin could require a higher amount of ADP and higher heating temperature. Stofko (1980) states that the transformation of polymeric starches, such as potato starch, into furan-type compounds requires a somewhat higher proportion of catalyst than simpler sugars, such as glucose and sucrose, for a given reaction rate. Therefore, the lowest TS and WA values of maltodextrin-based particleboard was achieved at higher catalyst contents and pressing temperatures, i.e. $20 \mathrm{wt} \%$ at $220^{\circ} \mathrm{C}$, while the same TS value could be achieved at $180^{\circ} \mathrm{C}$ for sucrose-based particleboard (Widyorini 2020).

The average surface roughness of the boards ranged between 4.94 to $8.14 \mu \mathrm{m}$ (Table 3). The lowest surface roughness was obtained from the 80/20 wt\% maltodextrin/ADP ratio and $220{ }^{\circ} \mathrm{C}$ pressing temperature. This was the only surface roughness found within average roughness values of commercial particleboard in Japan, which range from 3.67 to 5.46 (Hiziroglu and Suzuki 2007). Compared to Santoso et al. (2017), who also used maltodextrin, the surface roughness of Salacca frond particleboard with a 100/0 wt $\%$ maltodextrin/ADP ratio at $200{ }^{\circ} \mathrm{C}$ had lower values than Nipa frond particleboard with the same treatment $( \pm 8.5 \mu \mathrm{m})$. Differences in particle size distribution and raw material type could be the reason for the different values (Nemli et al. 2005; Hashim et al. 2010). Increasing the ADP ratio and pressing temperature decreased the surface roughness values (a smaller $R_{\mathrm{a}}$ resulted in better board quality) which may be due to increased density board and decreased moisture content. Increased density and decreased moisture content lowered the surface roughness values of the particleboard (Hiziroglu and Suchland 1993; Nemli et al. 2005).

\section{Mechanical Properties of Boards}

The IBS values of the boards are shown in Fig. 1. All boards satisfied JIS A 5908 requirement type 18 (min. $0.3 \mathrm{MPa}$ ), except the $100 / 0 \mathrm{wt} \%$ maltodextrin/ADP ratio at 200 ${ }^{\circ} \mathrm{C}$, which satisfied JIS requirement type 13 (min. $0.2 \mathrm{MPa}$ ). The IBS value of the maltodextrin-bonded Salacca frond particleboard was $0.25 \mathrm{MPa}$, while that of the 
maltodextrin-bonded nipa frond particleboard was 0.16 MPa (Santoso et al., 2017) at 200 ${ }^{\circ} \mathrm{C}$ pressing temperature. These results indicated that maltodextrin is potential material for adhesive. Based on Fig 1., it shows that to utilize maltodextrin as an adhesive, it needs at least $200^{\circ} \mathrm{C}$ pressing temperature. After the pressing temperature was increased to $220^{\circ} \mathrm{C}$, the IBS value of maltodextrin-based particleboard could increase to $0.5 \mathrm{MPa}$. The higher pressing temperature approached the melting and curing point of maltodextrin better than lower pressing temperatures, and also the bonding occurred between maltodextrin and particles and produced higher IBS values. The melting point of maltodextrin is higher than $225{ }^{\circ} \mathrm{C}$ (Mollan and Celik 1996), while that of ADP is around 203 to $208{ }^{\circ} \mathrm{C}$ (Umemura et al. 2017). With addition of 10\% ADP, an endothermic peak was observed at around $204{ }^{\circ} \mathrm{C}$ (Dewi et al. 2020). Figure 1 shows that addition of $20 \%$ ADP caused the increasing of IBS values until around $0.43 \mathrm{MPa}\left(200^{\circ} \mathrm{C}\right)$ or $0.62 \mathrm{MPa}\left(220^{\circ} \mathrm{C}\right)$. Widyorini et al. (2018) showed that maltodextrin and citric acid could provide the optimum IBS value of Salacca frond particleboard $(0.67 \mathrm{MPa})$ when the ratio citric acid/maltodextrin ratio was $75 / 25$ with a $180{ }^{\circ} \mathrm{C}$ pressing temperature. It was clearly shown that the bonding properties of maltodextrin can be improved by cross-linking agent, such as citric acid (Widyorini et al. 2018), or addition of a catalyst, such as ADP in this research.

The IBS values increased remarkably with increased pressing temperatures, and a $10 \mathrm{wt} \%$ ADP addition in the maltodextrin increased IBS values remarkably compared to the maltodextrin without ADP. However, further addition (20 wt $\%$ ADP) had similar IBS values compared to $10 \mathrm{wt} \%$ ADP. This result was similar to Zhao et al. (2018) and Widyorini (2020), but the effect of increasing pressing temperatures from 180 and $200{ }^{\circ} \mathrm{C}$ to $220{ }^{\circ} \mathrm{C}$ in the sucrose/ADP $(85 / 15 \mathrm{wt} \%)$ particleboard did not increase the IBS value remarkably. As mentioned above, the curing mechanism of maltodextrin-based adhesive was expected to be related to caramelization and the forming of furan-type compounds/furan derivative, i.e. 5-hydroxymethyl 2-furfural (5-HMF), that is produced by the dehydration of saccharides-based materials/carbohydrates with/without catalyst in heat treatment (Tomasik et al. 1989; Chheda et al. 2007).

The range of MOR and MOE values was 8.5 to $10.4 \mathrm{MPa}$ and 2.37 to $3.15 \mathrm{GPa}$, respectively (Fig. 2). All boards met MOR and MOE requirements of JIS A 5908 type 8 (min. $8 \mathrm{MPa}$ and min. $2 \mathrm{GPa}$ ). Some boards even met the MOE requirement of the JIS A 5908 type 18 (min. $3 \mathrm{GPa}$ ). Results showed the boards exhibited moderate MOR values but had high elasticity. The MOR values were not particularly affected by the maltodextrin/ADP ratios and pressing temperatures due to the same value in all treatments. The interaction between the pressing temperature and adhesive composition also did not notably affect the MOR values of the Salacca frond particleboard with acid citric/maltodextrin $100 / 0$ to $50 / 50 \mathrm{wt} \%$ at 180 and $200{ }^{\circ} \mathrm{C}$ (Widyorini et al. 2018). The use of the same particle size and the treatment type could be the reasons for inconsequential MOR value changes because particle size affected the MOR values (Widyorini et al. 2016). 


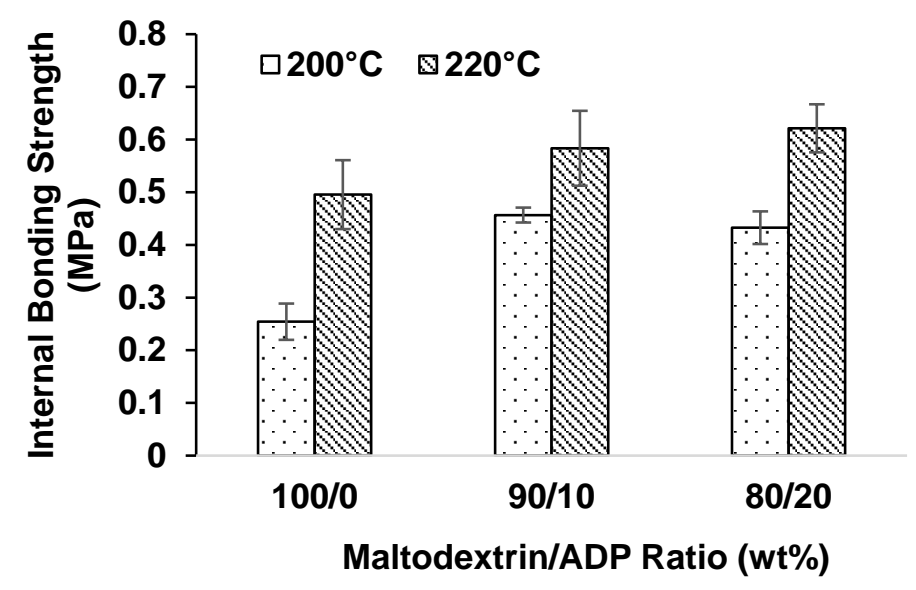

Fig. 1. IBS of particleboard at various maltodextrin/ADP ratios and pressing temperatures; vertical line through the bars represents standard deviation from the mean

Figure 3 shows the reduction of bending strength after hot water treatment. Particleboards made with the 100/0 wt $\%$ maltodextrin/ADP ratio and 90/10 wt\% maltodextrin/ADP ratio at $200{ }^{\circ} \mathrm{C}$ had a $100 \%$ strength reduction because the sample was damaged after hot water treatments. However, the reduction of the MOR and MOE values after treatments decreased remarkably with increased ADP additions and pressing temperatures. Interestingly, it clearly showed that the increasing of IB values and decreasing of the TS and WA values correlated to the improving wet bending strength of the boards.

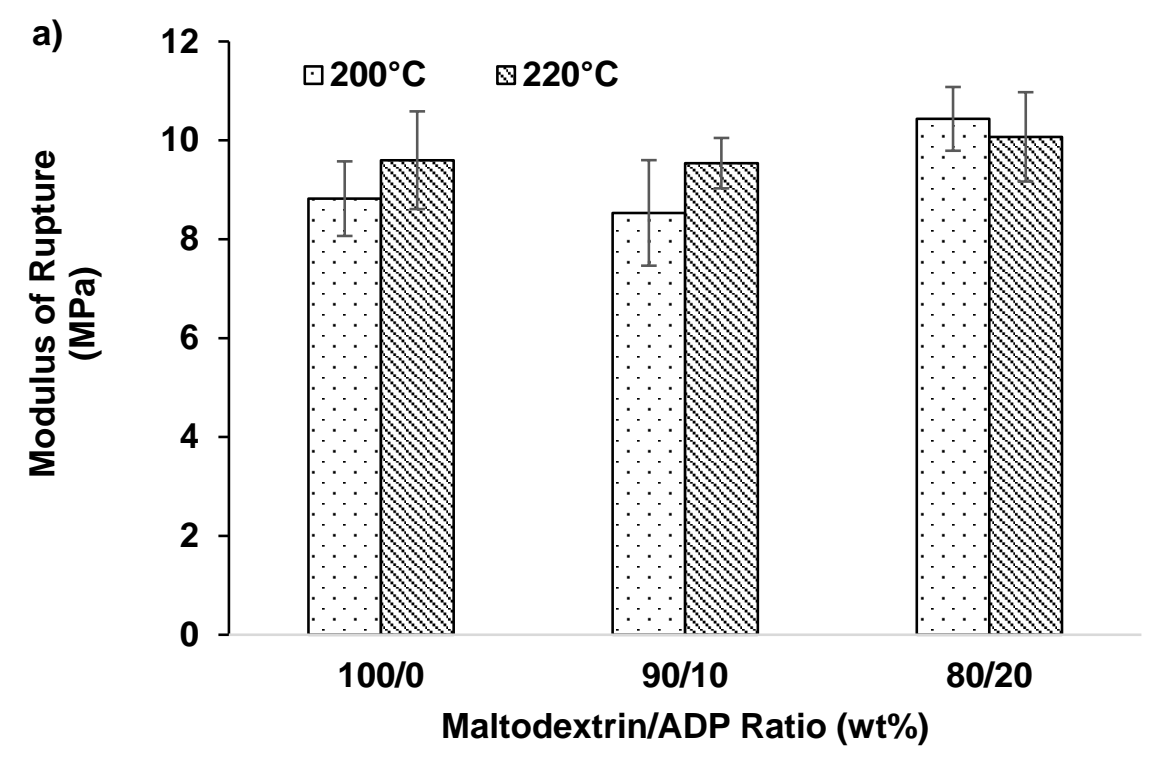




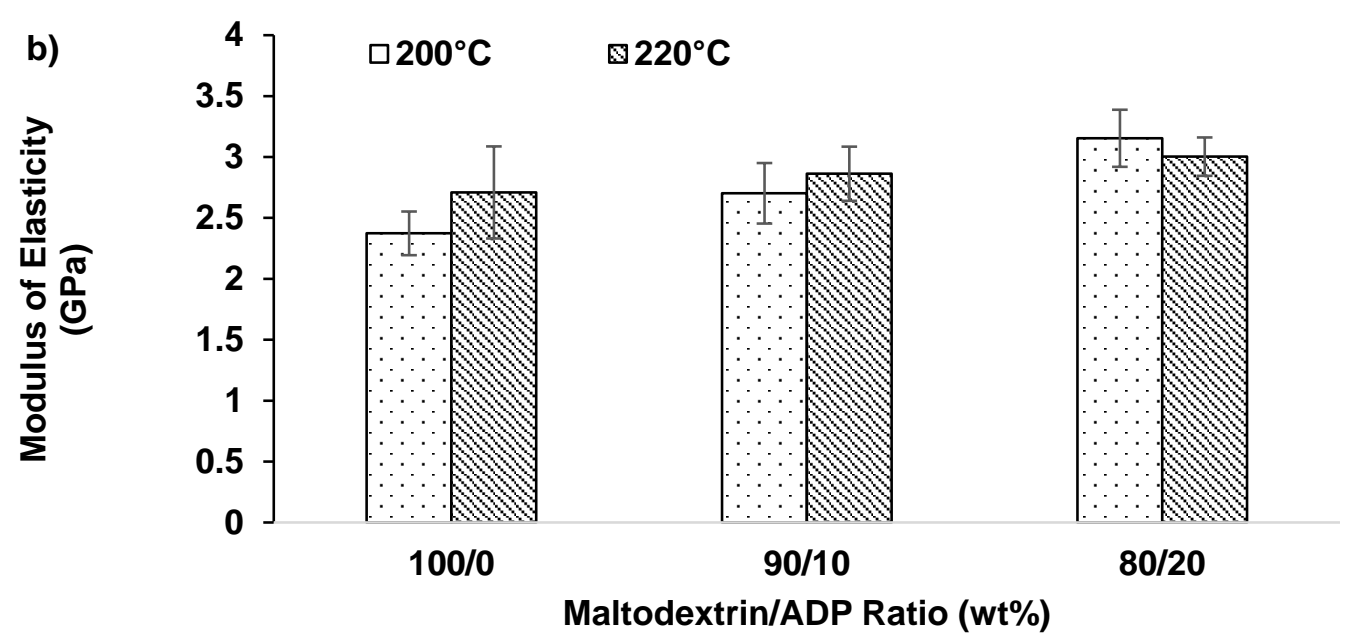

Fig. 2. a) MOR and b) MOE of particleboard under dry conditions at various maltodextrin/ADP ratios and pressing temperatures; vertical line through the bars represent standard deviation from the mean

\section{Fourier Transform Infrared (FTIR)}

The FTIR spectra of Salacca frond particle, the adhesive of maltodextrin /ADP (80/20), as well as the particleboards at different ADP ratios and pressing temperatures, are shown in Fig. 4. The peak at $2924 \mathrm{~cm}^{-1}$ was attributed to $\mathrm{C}-\mathrm{H}$ stretching of $\mathrm{CH}_{2}$ (Parikh and Madamwar 2006). Figure 4 shows that the absorbance of the peak of $2924 \mathrm{~cm}^{-1}$ for maltodextrin-bonded particleboard was stronger compared other boards. The peaks at around 1705 and 1636/1620 $\mathrm{cm}^{-1}$ would be attributed to carbonyl groups. The peaks at 1512 and $794 \mathrm{~cm}^{-1}$ were attributed to $\mathrm{C}=\mathrm{C}$ and $\mathrm{CH}=\mathrm{CH}$ of furan ring (Beta et al. 2001; Billes et al. 2004; Umemura et al. 2017). Those absorption bands increased with increasing pressing temperature, indicating promotion of the curing process along the polymerization of the furan compounds, as mentioned by Zhao et al. (2019). Meanwhile, the peak at around of $1512 \mathrm{~cm}^{-1}$ can be attributed to $\mathrm{C}=\mathrm{C}$ stretching vibration furan ring (Umemura et al. 2017; Zhao et al. 2019), as well as to $\mathrm{C}=\mathrm{C}$ stretching of the benzene ring in lignin (Kubovsky et al. 2020) as shown at Salacca frond and the particleboards. The FTIR spectra showed that the maltodextrin/ADP based particleboard and maltodextrin/ADP dried adhesive had the peak of $794 \mathrm{~cm}^{-1}$, while the maltodextrin-based particleboard and Salacca frond had not. Based on the results, ADP seemed act as catalyst for maltodextrin, in presence of heat treatment, to caramelize and lead to 5HMF formation, as mentioned by Tomasik et al. (1989). 


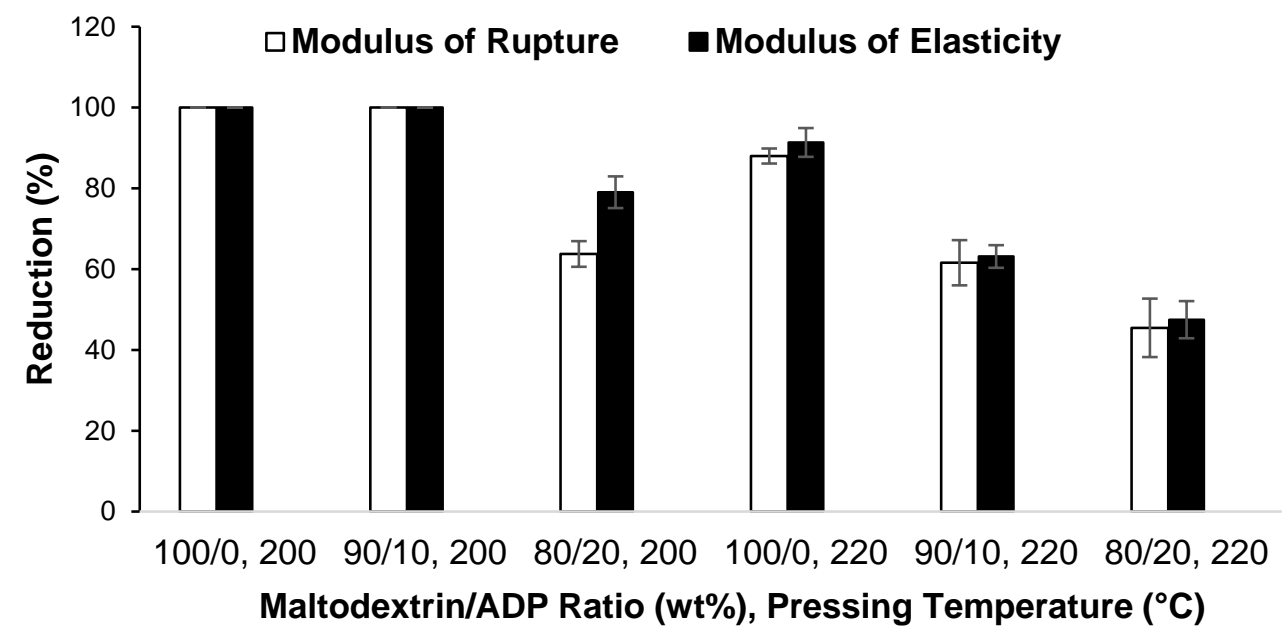

Fig. 3. MOR and MOE reductions after hot water treatment; vertical line through the bars represent standard deviation from the mean

\section{Thermogravimetry Analysis (TGA)}

Figure 5 shows the TGA of dried mixtures of maltodextrin/ADP added Salacca frond particles and maltodextrin/ADP (Dewi et al. 2019). The dried mixture of maltodextrin/ADP added particles was composed of maltodextrin, ADP, and Salacca frond, that reflect the composition of the mat. Based on Dewi et al. (2019), the onset temperature of weight reduction of dried mixtured of only maltodextrin $(100 / 0 \mathrm{wt} \%)$ at around $270{ }^{\circ} \mathrm{C}$, which is similar with Castro et al. $(2016)$, i.e. $266^{\circ} \mathrm{C}$. It can be seen that the preliminary weight loss temperatures of maltodextrin added particles was around $204{ }^{\circ} \mathrm{C}$, as shown in Fig. 5. This behavior of the decomposition is principally attributed to the three main components of the lignocellulosic material (hemicellulose, cellulose, and lignin) of Salacca frond, considering that the dried mixture was around $83 \mathrm{wt} \%$ composed of the biomass.

Figure 5 shows that when ADP of $20 \mathrm{wt} \%$ was added to maltodextrin, the onset temperature of weight reduction was around $188^{\circ} \mathrm{C}$. Umemura et al. (2017) showed that the onset temperature of weight reduction of $\mathrm{ADP}$ was around $170{ }^{\circ} \mathrm{C}$. When that mixture was added to the Salacca frond particles, the preliminary weight loss temperatures was approximately $156{ }^{\circ} \mathrm{C}$. Those phenomena showed that ADP addition caused lowering the onset temperature of weight reduction. Komariah et al. (2019) also resulted that when ADP was added to oil palm trunk (OPT) particles, the degradation of OPT shifted to lower temperature. These findings indicated that the thermal degradation and caramelization reactions of maltodextrin shifted at a lower temperature with the addition of ADP, as also has been occurred on sucrose, as mentioned by Zhao et al. (2019). Shorter chain saccharides and 5-HMF have a lower melting point than longer chain saccharides (Shallenberger and Birch 1975; Rosatella et al. 2011), which may be one of the reasons the onset degradation temperature occurred at lower temperatures. 


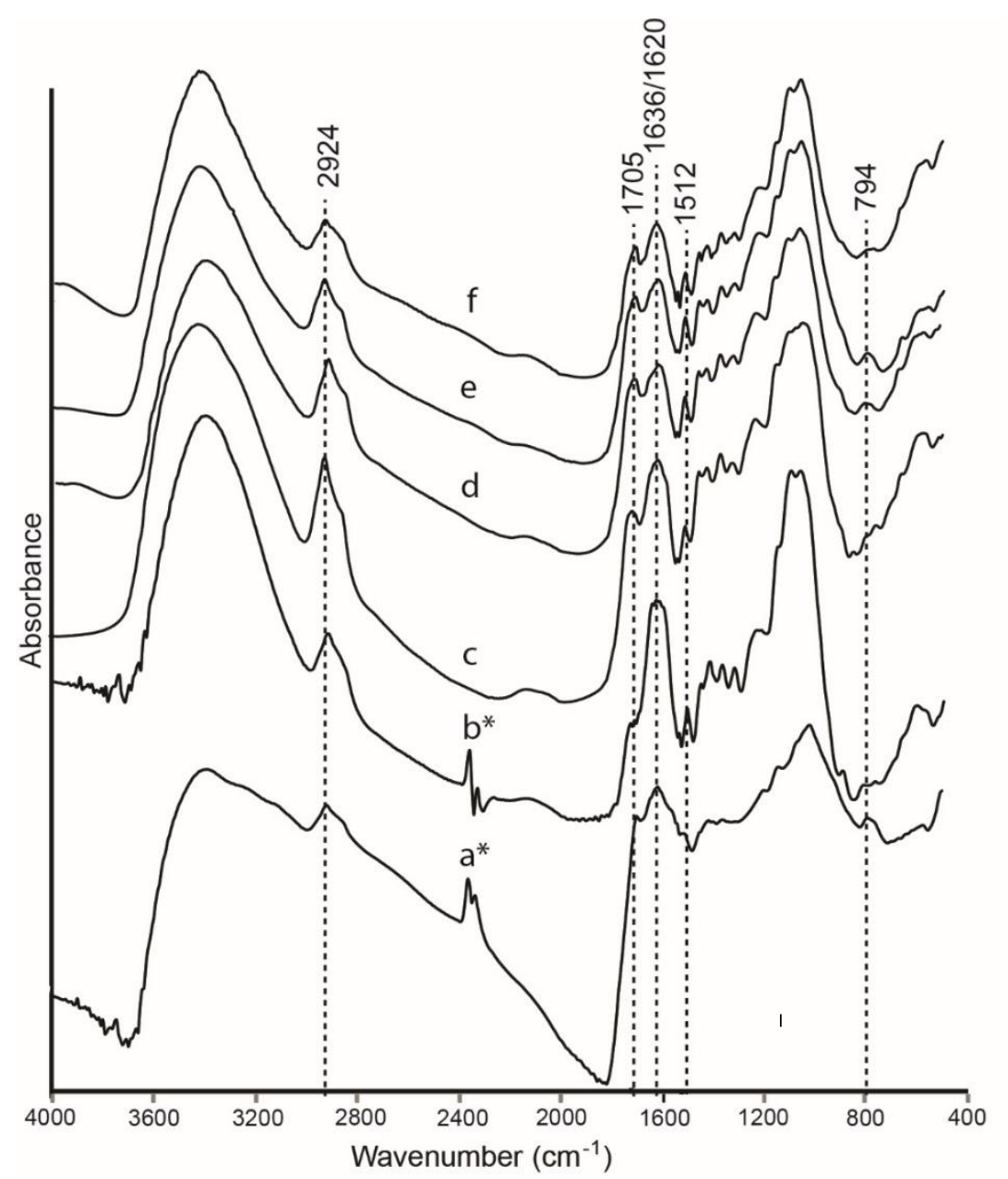

Fig. 4. FTIR spectra of several samples $\left.a^{*}\right)$ dried mixture of maltodextrin/ADP $(80 / 20 w t \%$, $\left.220^{\circ} \mathrm{C}\right)$ (Dewi et. al. 2020), b*) Salacca frond particles (Widyorini et al. 2018), c) particleboard (maltodextrin/ADP: $100 / 0 \mathrm{wt} \%, 220^{\circ} \mathrm{C}$ ), d) particleboard (maltodextrin/ADP: $90 / 10 \mathrm{wt} \%, 220^{\circ} \mathrm{C}$ ), e) particleboard (maltodextrin/ADP: $80 / 20 \mathrm{wt} \%, 220^{\circ} \mathrm{C}$ ), f) particleboard (maltodextrin/ADP: 80/20 wt $\left.\%, 200^{\circ} \mathrm{C}\right)$ 


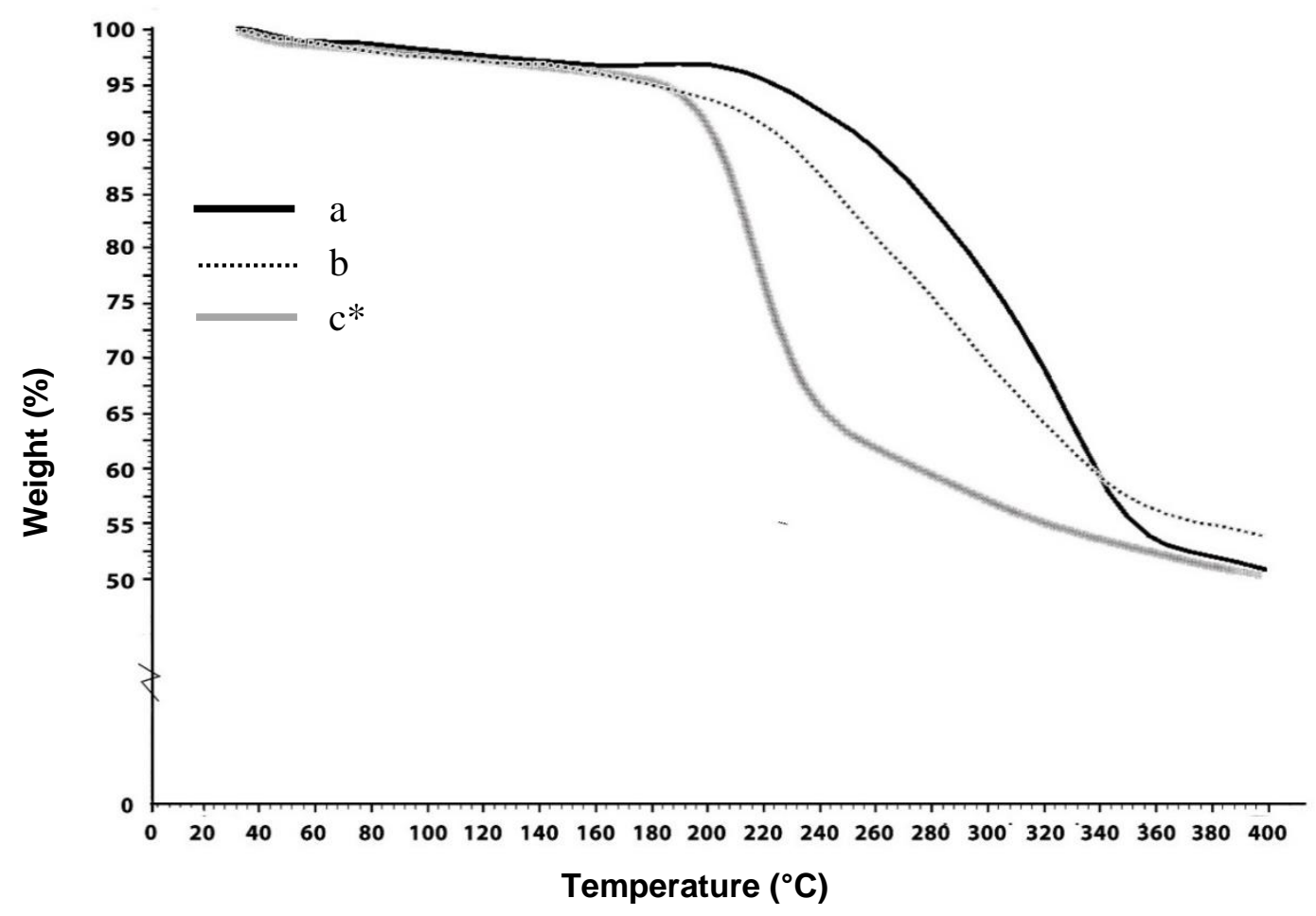

Fig. 5. Thermogravimetry curve of a) the maltodextrin/ADP (100/0 wt $\%$ )-added Salacca frond particles, b) the maltodextrin/ADP (80/20 wt\%)-added Salacca frond particles, and c*) dried mixture adhesive of maltodextrin/ADP (80/20 wt\%) (Dewi et. al. 2019)

\section{CONCLUSIONS}

1. A combination of increased ammonium dihydrogen phosphate (ADP) ratio in maltodextrin and increased pressing temperature improved the properties of Salacca frond particleboard, especially the properties related to water treatment. This result was consistent with a catalytic effect of ADP in caramelization/the rearrangement of maltodextrin into a high-water resistance substance, i.e. 5-hydroxymethyl 2-furfural (5HMF).

2. The best particleboard manufacturing condition found in this research was the $80 / 20$ $\mathrm{wt} \%$ maltodextrin/ADP ratio at a $220{ }^{\circ} \mathrm{C}$ pressing temperature, and the properties met the requirement of JIS A 5908.

\section{ACKNOWLEDGMENTS}

Part of this research was financially supported by Ministry of Research, Technology and Higher Education of the Republic of Indonesia and Universitas Gadjah Mada, under research grant of the PDUPT (2019-2021) scheme. 


\section{REFERENCES CITED}

Akyildiz, M. H. and Ates, S. (2008). "Effect of heat treatment on equilibrium moisture content (EMC) of some wood species in Turkey," Res. J. Agr. Biol. Sci. 4(6), 660665.

Axelson, L. (2015). "Outlook for formaldehyde and impact on methanol demand," in: Proc. of Annual IHS Chemical World Methanol 2015 Conference, Munich, Germany, pp. 24.

Bemiller, N. and Whistler, R. L. (1996). "Carbohydrates," in: Food Chemistry, O. R. Fennema (ed.), Marcel Dekker, New York.

Bertaud, F., Lingua, S. T., Pizzi, A., Navarrete, P., and Conil, M. P. (2012). "Development of green adhesives for fiberboard manufacturing, using tannins and lignin from pulp mill residues," Cell. Chem. Technol. 46(7-8), 449-455.

Beta, I. A., Jobic, H., Geidel, E., Böhlig, H., and Hunger, B. (2001). "Inelastic neutron scattering and infrared spectroscopic study of furan adsorption on alkali-metal cationexchanged faujasites," Spectrochim. Acta A 57(7), 1393-1403. DOI: 10.1016/s13861425(00)00481-9

Billes, F., Böhlig, H, Ackermann, M., and Kudra, M. (2004). “A vibrational spectroscopic study on furan and its hydrated derivatives," J. Mol. Struct.-Theochem 672(1-3), 1-16. DOI: 10.1016/j.theochem.2003.10.067

BPPT (2000). Budidaya Pertanian Salak (Salacca edulis) [Salacca (Salacca edulis) Agricultural Cultivation], Badan Pengkaji dan Penerapan Teknologi Kementerian Riset dan Teknologi RI, Jakarta, Indonesia.

Castro-Cabado, M., Parra-Ruiz, F., Casado, A. L., and Román, J. S. (2016). “Thermal crosslinking of maltodextrin and citric acid. Methodology to control the polycondensation reaction under processing conditions," Polym. Polym. Compos. 24(8), 643-654. DOI: 10.1177/096739111602400803

Castro, N., Durrieu, V., Raynaud, C., and Rouilly, A. (2016). "Influence of DE-value on the physicochemical properties of maltodextrin for melt extrusion processes," Carbohydr. Polym. 144, 464-473. DOI: 10.1016/j.carbpol.2016.03.004

Chheda, J. N., Román-Leshkov, Y., and Dumesic, J. A. (2007). "Production of 5hydroxy-methylfurfural and furfural by dehydration of biomass-derived mono- and poly-saccharides," Green Chem. 9(4), 342-350. DOI: 10.1039/b611568c

Clare, A. B., Franich, R. A., Lomax, T. D., McDonald, A. G., and Meder, R. (2002). "Preparation, characterization, and performance of cross-linkable maltodextrin based lignocellulosic adhesives," J. Adhes. Sci. Technol. 16(3), 317-329. DOI: $10.1163 / 156856102317295513$

Clarke, S. A. (1966). "Plywood and other wood based panels," Unasylva 16(3).

Claude, J., and Ubbink, J. (2006). "Thermal degradation of carbohydrate polymers in amorphous states: A physical study including colorimetry, " Food Chem. 96(3), 402410. DOI:10.1016/j.foodchem.2005.06.003

Dewi, G. K., Widyorini, R., and Lukmandaru, G. (2019). Effect of Ammonium Dihydrogen Phosphate (ADP) Catalyst Addition on Maltodextrin Adhesives Properties and Salacca Frond Particleboard Properties (Unpublished master's thesis). Gadjah Mada University.

Dewi, G. K., Widyorini, R., and Lukmandaru, G. (2020). "Effect of ammonium dihydrogen phosphate (ADP) addition as catalyst on the curing maltodextrin 
adhesives properties," Key Eng. Mater. 840, 551-557. DOI:

10.4028/www.scientific.net/KEM.840.551

Esteves, B. M., and Pereira, H. M. (2009). "Wood modification by heat treatment: A review," BioResources 4(1), 370-404. DOI: 10.15376/biores.4.1.370-404

FAO (2018). Global Forest Product Facts and Figures 2017, Forestry Department, Food and Agriculture Organization of the United Nations, Rome, Italy.

Hakim, L., Widyorini, R., Nugroho, W. D., and Prayitno, T. A. (2019). "Anatomical, chemical, and mechanical properties of fibrovascular bundles of Salacca (snake fruit) frond," BioResources 14(4), 7943-7957. DOI: 10.15376/biores.14.4.7943-7957

Hashim, R., Saari, N., Sulaiman, O., Sugimoto, T., Hiziroglu, S., Sato, M., and Tanaka, R. (2010). "Effect of particle geometry on the properties of binderless particleboard manufactured from oil palm trunk," Mater. Design 31(9), 4251-4257. DOI: 10.1016/j.matdes.2010.04.012

Hiziroglu, S., and Suchsland, O. (1993). "Linear expansion and surface stability of particleboard," For. Prod. J. 43(4), 31-34.

Hiziroglu, S., and Suzuki, S. (2007). "Evaluation of surface roughness of commercially manufactured particleboard and medium density fiberboard in Japan." J. Mater. Process. Tech. 184(1-3), 436-440. DOI: 10.1016/j.jmatprotec.2006.11.011

JIS A 5908 (2003). "Particleboards," Japanese Standards Association, Tokyo, Japan.

Kenyon, M. M. and Anderson, R. J. (1998). "Maltodextrins and low-dextroseequivalence corn syrup solids: production and technology for the flavor industry," in: ACS Symposium Series 370, S. J. Risch, and G. A. Reineccius (eds.), American Chemical Society, Washington DC, USA, pp. 7-11. DOI: 10.1021/bk-19880370.ch002

Kollman, F. F. P., Kuenzi, E. W., and Stamm, A. J. (2012). Principles of Wood Science and Technology II: Wood Based Materials, Springer-Verlag, Berlin, Germany. DOI: 10.1007/978-3-642-87931-9

Komariah, R. N., Miyamoto, T., Tanaka, S., Prasetiyo, K. W., Syamani, F. A., Subyakto, Umezawa, T., Kanayama, K., and Umemura, K. (2019). "High-performance binderless particleboard from the inner part of oil palm trunk by addition of ammonium dihydrogen phosphate," Ind. Crop. Prod. 141, 111761. DOI: 10.1016/j.indcrop.2019.111761

Kubovsky, I., Ka`cíková, D., and Ka`cík, F. (2020). “Structural changes of oak wood main components caused by thermal modification," Polymers 12, 485. DOI: 10.3390/polym 12020485

Lei, H., Pizzi, A., Navarrete, P., Rigolet, S., Redl, A., and Wagner, A. (2010). “Gluten protein adhesives for wood panels," J. Adhes. Sci. Technol. 24(8-10), 1583-1596. DOI: 10.1163/016942410X500963

Lim, T. K. (2012). Edible Medicinal and Non-Medicinal Plants, Volume 1, Fruits, Springer, New York.

Mollan, M. J. and Çelik, M. (1996). "Maltodextrin," in: Analytical Profiles of Drug Substances and Excipients (Vol. 24), H. G. Brittain (ed.), Academic Press, Inc., New Jersey, NJ. DOI: 10.1016/S0099-5428(08)60697-8

Moubarik, A., Allal, A., Pizzi, A., Charrier, P., and Charrier, B. (2009). "Characterization of a formaldehyde-free cornstarch-tannin wood adhesive for interior plywood," Eur. J. Wood Wood Prod. 68, 427-433. DOI: 10.1007/s00107-009-0379-0

Nemli, G., Ozturk, I., and Aydin, I. (2005). "Some of the parameters influencing surface 
roughness of particleboard," Build. Environ. 40(10), 1337-1340. DOI:

10.1016/j.buildenv.2004.12.008

Norstrom, E., Fogelstrom, L., Nordqvist, P., Khabbaz, F., and Malmstrom, E. (2014).

"Gum dispersions as environmentally friendly wood adhesives," Ind. Crop. Prod. 52, 736-744. DOI: 10.1016/j.indcrop.2013.12.001

Parikh, D., and Madamwar. (2006). "Partial characterization of extracellular polysaccharides from cyanobacteria," Bioresource Technol. 97(15), 1822-1827. DOI: 10.1016/j.biortech.2005.09.008

Prasetyo, B. D., Widyorini, R., and Prayitno, T. A. (2017). "Mutu papan partikel pelepah salak tiga lapis berperekat asam sitrat [The quality of citric acid bonded three layered particle board of snake fruit frond]," J. Trop. Wood Sci. Technol. 15(2), 185-192.

Quintas, M. A. C., Brandão, T. R. S., and Silva, C. L. M. (2007). "Modelling colour changes during the caramelisation reaction," J. Food Eng. 83(4), 483-491. DOI: 10.1016/j.jfoodeng.2007.03.036

Rosatella, A. A., Simeonov S. P., Frade, R. F., and Afonso, C. A. (2011). "5hydroxymethyl-furfural (HMF) as a building block platform: Biological properties, synthesis and synthetic applications," Green Chem. 13(4), 754-793. DOI: 10.1039/C0GC00401D

Rowe, R. C., Sheskey, P. J., and Marian, E. Q. (2009). Handbook of Pharmaceutical Excipients (6th ed.). Pharmaceutical Press and the American Pharmacist Association, London and Washington DC.

Saleh, M. S. M., Siddiqui, M. J., Mediani, A., Ismail, N. H., Ahmed, Q. U., So'ad, S. Z. M., and Saidi-Besbes, S. (2018). "Salacca zalacca: A short review of the palm botany, pharmacological uses and phytochemistry," Asian Pac. J. Trop. Med. 11(12), 645-652. DOI: 10.4103/1995-7645.248321

Santoso, M., Widyorini, R., Prayitno, T. A., and Sulistyo, J. (2017). "Bonding performance of maltodextrin and citric acid for particleboard made from nipa fronds," J. Korean Wood Sci. Technol. 45(4), 432-443. DOI: 10.5658/WOOD.2017.45.4.432

Sekino, N., Inoue, M., Irle, M., and Adcock, T. (1999). "The mechanism behind the improved dimensional stability of particleboards made from steam-pretreatment particles," Holzforschung 53(4), 435-440. DOI: 10.1515/HF.1999.072

Shallenberger, R. S., and Birch, G.G. (1975). Sugar Chemistry, AVI Publishing Co., Inc., Westport, CT, USA.

Statistic Indonesia. (2019). "Statistics of annual fruits and vegetable plants 2018," Subdirectorate of Holticulture Statistics, Statictics Indonesia, Jakarta.

Stofko, J. (1980). "Bonding of solid lignocelullosic material," U.S. Patent No. US4183997A

Tomasik, P., Pakasiński, M., and Weijak, S. (1989). "The thermal decomposition of carbohydrates. Part 1. The decomposition of mono-, di-, and oligo-saccharides," Adv. Carbohydr. Chem. Biochem. 47, 203-278. DOI: 10.1016/S0065-2318(08)60415-1

Umemura, K., Hayashi, S., Tanaka, S., and Kanayama, K. (2017). "Changes in physical and chemical properties of sucrose by the addition of ammonium dihydrogen phosphate," J. Adhes. Soc. Jpn. 53(4), 112-117. DOI: 10.11618/adhesion.53.112

Umemura, K., Inoue, A., and Kawai, S. (2003). "Development of new natural polymerbased wood adhesives I: Dry bond strength and water resistance of konjac glucomannan, chitosan, and their composites," J. Wood Sci. 49, 221-226. DOI: 10.1007/s10086-002-0468-8

Umemura, K., Ueda, T., Munawar, S. S., and Kawai, S. (2011). “Application of citric 
acid as natural adhesive for wood," J. Appl. Polym. Sci. 123(4), 1991-1996. DOI: 10.1002/app.34708

Wang, Y. J. and Wang, L. (2000). "Structures and properties of commercial maltodextrins from corn, potato, and rice starches," Starch-Starke 52(8-9), 296-304. DOI: 10.1002/1521-379X(20009)52:8/9<296::AID-STAR296>3.0.CO;2-A

Widyorini, R. (2020). "Evaluation of physical and mechanical properties of particleboard made from petung bamboo using sucrose-based adhesive," BioResources 15(3), 5072-5086. DOI: 10.15376/biores.15.3.5072-5086

Widyorini, R., Aji, K. B., Anisa, D. N., and Dewi, G. K. (2020). "Properties of particleboard made from Salacca (Salacca sp) frond," IOP Conf. Ser. Earth Environ. Sci. 449, 012025. DOI: 10.1088/1755-1315/449/1/012025

Widyorini, R., Umemura, K., Isnan, R., Putra, D. R., Awaludin, A., and Prayitno, T. A. (2016). "Manufacture and properties of citric acid-bonded particleboard made from bamboo materials," Eur. J. Wood Wood Prod. 74(1), 57-65. DOI: 10.1007/s00107015-0967-0

Widyorini, R., Umemura, K., Kusumaningtyas, A. P., and Prayitno, T. A. (2017). "Effect of starch addition on properties of citric acid bonded particleboard made from bamboo," BioResources 12(4), 8068-8077. DOI: 10.15376/biores.12.4.8068-8077

Widyorini, R., Umemura, K., Septiano, A., Soraya, D. K., Dewi, G. K., and Nugroho, W. D. (2018). "Manufacture and properties of citric acid-bonded composite board made from Salacca frond: Effect of maltodextrin addition, pressing temperature, and pressing method," BioResources 13(4), 8662-8676. DOI: 10.15376/biores.13.4.86628676

Zhao, Z., Hayashi, S., Xu, W., Wu, Z., Tanaka, S., Sun, S., Zhang, M., Kanayama, K., and Umemura, K. (2018). "A novel eco-friendly wood adhesive composed by sucrose and ammonium dihydrogen phosphate," Polymers-Basel 10(11), 1251. DOI: 10.3390/polym 10111251

Zhao, Z., Sun, S., Wu, D., Zhang, M., Huang, C., Umemura, K., and Yong, Q. (2019). "Synthesis and characterization of sucrose and ammonium dihydrogen phosphate (SADP) adhesive for plywood," Polymers 11(12), 1909. DOI:

10.3390/polym 11121909

Article submitted: December 7, 2020; Peer review completed: February 27, 2021; Revised version received and accepted: November 6, 2021; Published: November 12, 2021.

DOI: 10.15376/biores.17.1.190-206 